\title{
Outpatient

\section{Celiac Disease: Celiac Sprue, Gluten-sensitive Enteropathy}

\author{
Anita I. Gheller-Rigoni, DO, Department of Internal Medicine, Marshfield Clinic, Marshfield, Wisconsin \\ Steven H. Yale, MD, Department of Internal Medicine, Marshfield Clinic, Marshfield, Wisconsin \\ Ahmad S. Abdulkarim, MD, Departments of Gastroenterology and Hepatology, Marshfield Clinic, Marshfield, Wisconsin
}

\section{REPRINT REQUESTS:}

Steven Yale, MD

Department of Internal Medicine

Marshfield Clinic

1000 North Oak Avenue

Marshfield, WI 54449

Telephone: 715-387-5436

Fax: 715-389-3808

Email: yale.steven@marshfieldclinic.org

KEYWORDS:

Celiac disease; Malabsorption syndromes;

Gluten; Inflammation; Small intestine; Intestinal absorption; Malnutrition
Clinical Medicine \& Research

Volume 2, Number 4: 71-72 (O)2004 Clinical Medicine \& Research http://www.mfldclin.edu/clinmedres
What is Celiac Disease?

Celiac Disease (CD) or gluten-sensitive enteropathy is a T-cell mediated disease occurring in genetically susceptible individuals induced by the ingestion of one of several proteins found in wheat (gliadins), barley (hordeins) and rye (secalinin). Symptoms classically include episodic diarrhea, abdominal pain and distention and weight loss. Approximately one half of adults develop clinically significant diarrhea. Interestingly, only one half of all patients with CD have symptoms referable to the gastrointestinal tract.

\section{What is the most common presentation of CD?}

The most common clinical presentation is iron-deficiency anemia due to both iron malabsorption and occult gastrointestinal bleeding. CD should be considered in any patient presenting with unexplained iron deficiency anemia, even in the absence of gastrointestinal symptoms. Involvement of the small bowel can lead to watersoluble (B12, folic acid) and fat-soluble (A, D, K, E) vitamin malnutrition and calcium deficiency. Thus patients may go on to develop such symptoms as peripheral neuropathy, osteoporosis, ataxia and coagulopathy.

Infants with $\mathrm{CD}$ typically present with impaired growth, diarrhea and abdominal distention. Older children with severe, untreated CD may develop short stature, pubertal delays, rickets, dental enamel defects, behavioral disturbances and poor school performance. CD is associated with the human leukocyte antigen HLA-DQ2 in $90 \%$ to $95 \%$ of cases and HLA-DQ8 in the remaining $5 \%$ to $10 \%$ of cases.

\section{What is the diagnostic study of choice in CD?}

The definitive diagnosis of $\mathrm{CD}$ is made by fulfilling the triad of (1) a positive serologic test, (2) histologic findings of small-bowel biopsy specimens and (3) favorable clinical and serological response following a gluten-free diet. Histologic findings, suggestive of, but not pathognomonic for celiac's disease, include disruption of the normal villous morphology with villous atrophy and elongated crypts, decreased epithelial surface cell height, and increased lymphocytic infiltration into the mucosa.

Serologic markers are used to screen patients with suspected CD and/or monitor their response and adherence to treatment with a gluten-free diet. Serological studies currently in clinical use include IgA endomysial antibody (IgA-EMA) and IgA tissue transglutaminase antibody (IgA-tTG). Antigliadin antibodies IgA and IgG (AGA) have moderate sensitivity but are less specific compared to IgA-EMA 
and -tTG antibodies (table 1). Antigliadin antibodies are generally not useful clinically due to the emergence of the more sensitive and specific EMA and tTG antibodies, and therefore their use as a screening test is no longer recommended (table 2).

A diagnostic dilemma arises when either a serologic test or histologic specimen is positive, but not both. If the serologic test is positive and histologic specimen is negative for $\mathrm{CD}$, then the biopsy specimen should be reviewed and if necessary, repeated. If the serology is negative but the histology is positive or with inconclusive results, then consider IgA deficiency. If this study is still negative, consider other causes of enteritis. If no cause is found despite a thorough evaluation, then HLA genotyping should be considered. Though HLA-DQ2 and -DQ8 are not specific for CD, if they are not present, this essentially rules out the disease.

All of these antibodies can be used to monitory dietary compliance, with values becoming undetectable within 3 to 6 months after a gluten-free diet is instituted.

Table 1. Sensitivity and specificity of serological tests in celiac disease.

\begin{tabular}{lcc}
\hline Serological Test & Sensitivity (\%) & Specificity (\%) \\
\hline IgA AGA & $75-90$ & $82-95$ \\
IgG AGA & $69-85$ & $73-90$ \\
IgA EMA & $85-98$ & $97-100$ \\
IgA tTG & $93-96$ & $99-100$ \\
\hline
\end{tabular}

*Modified with permission from Abdulkarim AS, Murray JA.

Review Article: the diagnosis of celiac disease. Aliment Pharm Ther 2003;17:987-995.

\section{What follow-up, including laboratory and imaging, should be performed in patients with CD?}

Once the diagnosis of CD is made, early referral to a dietitian is essential for greater compliance of the complicated and costly gluten-free diet. Patients should be followed life long with annual weight, complete blood counts, folic acid, calcium, alkaline phosphatase and ferritin level determinations. Routine imaging should not be performed in patients with CD. Radiographic studies should be considered however, in patients who do not respond or partially respond to a gluten-free diet to exclude complications such as lymphoma, carcinoma, or ulcerative jejunoileitis.

\section{FURTHER READING}

Abdulkarim AS, Murray JA. Review Article: the diagnosis of celiac disease. Aliment Pharm Ther 2003;17:987-995.

Farrell FM, Ciaran KP. Celiac disease. N Engl J Med 2002;346: 180-188.

Farrell RJ, Kelly CP. Diagnosis of celiac disease. Am J Gastroenterol 2001;96:3237-3246.

Fasano A. Celiac disease-how to handle a clinical chameleon. N Engl J Med 2003;348:2568-2570.

McManus R, Kelleher D. Celiac disease-the villain unmasked? N Engl J Med 2003;348:2573-2574.

Olds G, Mcloughlin R, O'Morian C, Sivak MV. Celiac disease for the endoscopist. Gastrointest Endosc 2002;56:407-415.

Shamir R. Advances in celiac disease. Gastroenterol Clin N Am 2003;32:931-947.

Table 2. Comparison of serological endomysial vs. tissue transglutaminase antibody tests.

\begin{tabular}{|c|c|c|}
\hline & Endomysial (EMA) & Transglutaminase (tTG) \\
\hline \multirow[t]{3}{*}{ Source of antigen } & - Monkey esophagus & - $\quad$ Guinea pig \\
\hline & - Human umbilical cord & - Human \\
\hline & - Human jejunum & \\
\hline Substrate & $\begin{array}{l}\text { Endomysium (connective } \\
\text { tissue protein surrounding } \\
\text { smooth muscle): tTG } \\
\text { autoantibody }\end{array}$ & - $\quad$ Tissue transglutaminase \\
\hline Assay & - Indirect immunofluorescence & $\begin{array}{l}\text { - Enzyme-linked } \\
\text { immunosorbent }\end{array}$ \\
\hline \multirow[t]{4}{*}{ Limitations/Advantages } & - Expensive & - $\quad$ Lower cost \\
\hline & - Difficult to perform & - Less time consuming \\
\hline & $\begin{array}{l}\text { - Subjective interpretation of } \\
\text { immunofluorescence }\end{array}$ & $\begin{array}{l}\text { - Avoids subjective } \\
\text { interpretation of } \\
\text { immunofluorescence }\end{array}$ \\
\hline & & $\begin{array}{l}\text { Does not use Monkey } \\
\text { esophagus }\end{array}$ \\
\hline
\end{tabular}

